\title{
POLAROGRAPHIC STUDY OF URANIUM(VI) IN AQUEOUS SOLUTIONS OF LITHIUM HYDROXIDE
}

VERA ŽUTIĆ AND MARKO BRANICA

Center for Marine Research, Institute "Rudjer Boškovic", Zagreb (Yugoslavia)

(Received April 18th, 1970)

\section{INTRODUCTION}

The hydrolysis of uranium(VI) has been extensively studied in acid, and in neutral solutions (see for example the data summarized by Sillen and Martell ${ }^{1}$ ), where the formation of a precipitate sets a limit to further investigations in solution ${ }^{2}$. There are only few data on the nature of uranium(VI) species formed in highly alkaline solutions. Gurevich and Preobrazhenskaya ${ }^{3}$ reported that a "soluble uranate", which gives an absorption spectrum in the u.v. region, is formed by the thermal decomposition of uranyl peroxo complexes in $1 M$ sodium hydroxide solution. In their study of the electrochemical reduction of uranium(VI) in mixed sodium carbonate and sodium hydroxide solutions, Gierst and Lemaire ${ }^{4}$ reported a "new, colourless and highly unstable particle of uranium(VI) in hydroxide solutions, that is in rapid precipitation equilibrium". They were, however, able to follow the effect of the ionic strength upon its two reduction waves, and to ascribe a negative charge to the particle undergoing reduction, but they could not elucidate the electrode process itself in view of the fast precipitation and/or the interference of the carbonate added to slow it down.

On the basis of the analysis of the corresponding solid phase, and in agreement with the Chernyaev theory of uranyl complexation, it has been deduced by the Russian authors ${ }^{5}$ that the soluble particle is the uranyl aquo hydroxo complex $\left[\mathrm{UO}_{2}\right.$ $\left.(\mathrm{OH})_{3}\left(\mathrm{H}_{2} \mathrm{O}\right)_{3}\right]^{-}$. In contrast, Gierst and Lemaire ${ }^{4}$ suggested the uranyl group did not retain its individuality in the complex.

Our own preliminary study of precipitation, spectra and polarographic reduction of uranium(VI) in lithium hydroxide solutions ${ }^{6}$ has indicated the formation of a stable and soluble uranium(VI) hydroxo complex, when the ratio of lithium hydroxide to uranium exceeds about $50(\mathrm{pH} \geqq 12.5)$. It was found to give a well defined reduction wave at about $-1.0 \mathrm{~V} v \mathrm{~s}$. SCE. In connection with previous work on the precipitation and the hydrolysis of uranium $(\mathrm{VI})^{7-11}$, and on the electrochemical behaviour of uranyl peroxo complexes ${ }^{12}$, the polarographic technique has been used in the present work to improve the characterization of the uranium(VI) species in alkaline solutions. The present investigation is restricted to the analysis of the first reduction wave of uranium(VI), under conditions such that the complex is stable and soluble. 
EXPERIMENTAL

\section{Apparatus}

The polarographic curves were recorded on a Radiometer PO4 polarograph adapted for the three-electrode configuration. The drop time of the mercury electrodes $\left(m \leqq 0.5 \mathrm{mg} \mathrm{s}^{-1}\right)$ was kept constant with the help of an electromagnetic detacher. Potentiostatic electrolysis at a mercury pool electrode was performed by means of a Tacussel, ASA 4C electronic potentiostat, the electrolysis current being recorded and integrated automatically. For cyclic voltammetry experiments Chemtrix polarographic units were connected to a Tektronix 564 oscilloscope. The hanging mercury drop electrode was of the Kemula type. A thermostatted cell ${ }^{13}$ maintained at $25^{\circ} \pm$ $0.2^{\circ} \mathrm{C}$ was used for all experiments. The reference electrode was a saturated calomel electrode placed in a separate compartment connected to the cell by a salt bridge filled with the same supporting electrolyte as in the cell. $\mathrm{pH}$ measurements were performed with a Pye Master pH meter and a Radiometer G 200 B glass electrode.

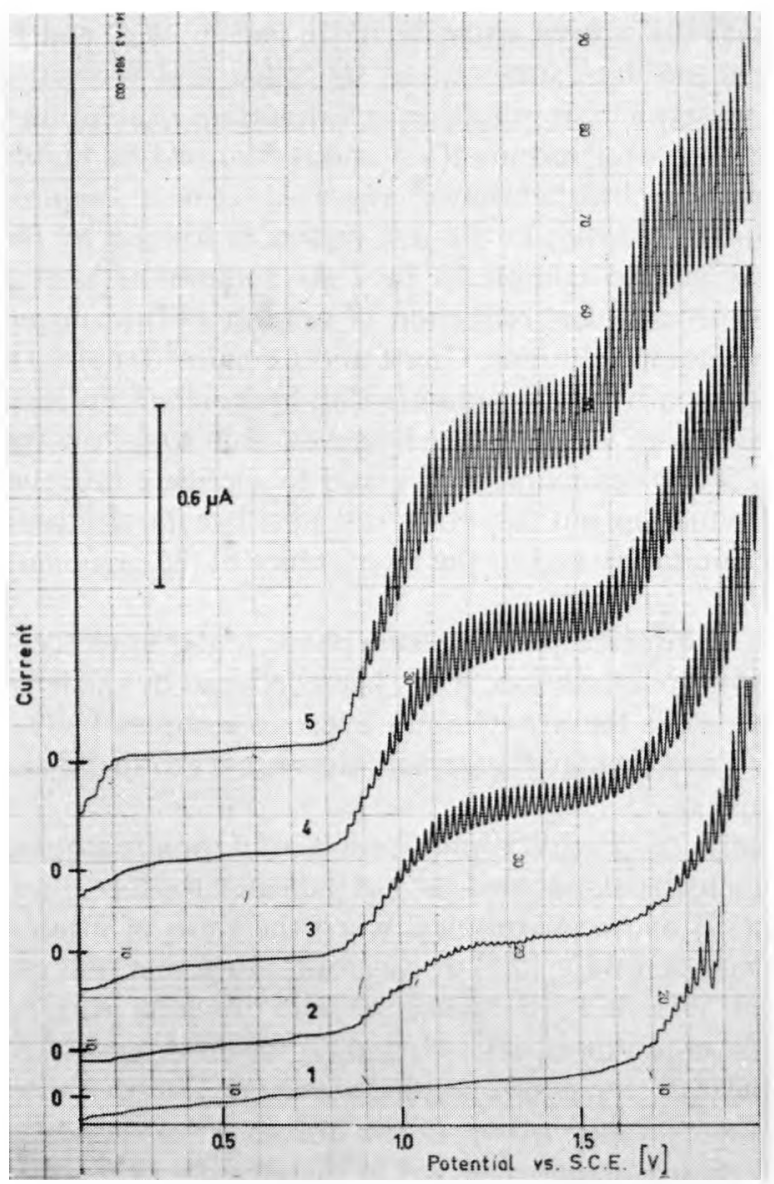

Fig. 1. Polarograms of $1 \mathrm{mM} \mathrm{UO}_{2}\left(\mathrm{ClO}_{4}\right)_{2}-0.1 \mathrm{MLiClO}_{4}-\mathrm{LiOH}_{\text {var }}$ [ [LiOH]: (1) $2.6 \times 10^{-3}$, (2) $10^{-2}$, (3) $2 \times 10^{-2}$, (4) $3 \times 10^{-2}$, (5) $5 \times 10^{-2} M$ solns. 


\section{Reagents and procedure}

A stock solution of uranyl perchlorate was obtained by dissolving uranyl perchlorate prepared via uranyl peroxide ${ }^{14}$. A saturated solution of lithium hydroxide $(\sim 5 M)$, purified over active charcoal, was diluted just prior to its use, in order to avoid contamination with carbonate. For the same reason freshly bidistilled water was used throughout.

The test solutions were prepared by mixing the components directly in the cell: a diluted solution of uranyl perchlorate was slowly added to the lithium hydroxide solution under vigorous stirring. The solutions were thoroughly deareated with prepurified nitrogen, and the nitrogen atmosphere was maintained throughout the experiments.

\section{RESULTS}

\section{Influence of $\mathrm{pH}$}

The effect of $\mathrm{pH}$ on the reduction wave of $1 \mathrm{mM}$ uranium(VI) has been investigated in $0.1 \mathrm{M} \mathrm{LiClO}_{4}$ with variable $\mathrm{LiOH}$ concentration. For the $\mathrm{LiOH}$ to uranium(VI) ratio of 2.6, the freshly prepared, clear and intensely coloured solution $(\mathrm{pH}=10.2)$ did not show any electroactive species reducible before the reduction potential of lithium (Fig. 1, curve 1). With gradual increase of the $\mathrm{LiOH}$ concentration, a well-defined reduction wave of uranium(VI) develops at about $-1.0 \mathrm{~V}$ vs. SCE (curves $2-5$ in Fig. 1), reaching a constant height at $[\mathrm{LiOH}] /[\mathrm{U}(\mathrm{VI})] \geqq 50(\mathrm{pH} \geqq 12.5)$. The dependence of the limiting current and of the half-wave potential on the concentration of the added lithium hydroxide is shown in Fig. 2. It is notable that the halfwave potential does not depend on the $\mathrm{pH}$; the slight trend towards more positive potentials at $\mathrm{LiOH} \geqq 0.05 M$ could be reasonably ascribed to the concomitant changing of ionic strength. The increase of the limiting current with the increasing $[\mathrm{LiOH}] /[\mathrm{U}(\mathrm{VI})]$ ratio, which can be correlated to pronounced spectral changes

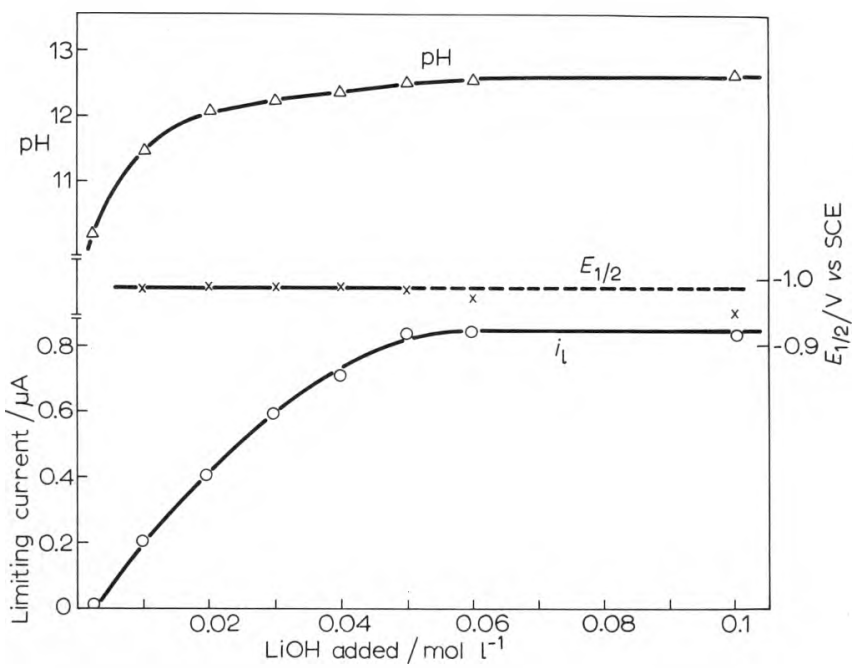

Fig. 2. Dependence of limiting current $(0)$ and of half-wave potential $(x)$ of uranium(VI) wave in $1 \mathrm{~m} M$ $\mathrm{UO}_{2}\left(\mathrm{ClO}_{4}\right)_{2}-0.1 \mathrm{M} \mathrm{LiClO}_{4}$ solns. on addition of $\mathrm{LiOH}$, and corresponding $\mathrm{pH}$ values $(\Delta)$. 
(the absorption maximum shifts from the visible to the U.V. region, $c f$. ref. 6 (Fig. 2) reflects the corresponding increase of the bulk concentration of the electroactive uranium(VI) species. The following experiments were therefore performed with mixtures such that $\mathrm{pH} \geqq 12.5$, and $[\mathrm{LiOH}] /[\mathrm{U}(\mathrm{VI})] \geqq 50$, for which the limiting current reaches its maximum value.

\section{Behaviour in $1 \mathrm{M} \mathrm{LiOH}$}

Uranium(VI) gives a reduction wave at $-0.88 \mathrm{~V}$ vs. SCE (Fig. 3, curve 1) with the theoretical slope expected for a one-electron reversible reduction. The dependence of the limiting current on the drop time $\left(\mathrm{d} \ln i_{1} / \mathrm{d} \ln t \simeq 0.2\right)$, as well as the temperature coefficient of the limiting current $\left(1.7 \% /{ }^{\circ} \mathrm{C}\right.$, in the range $\left.10-40^{\circ} \mathrm{C}\right)$ demonstrate that the current is diffusion controlled. The fact that the limiting current is proportional to the concentration of uranium(VI) (Fig. 4), while the half-wave potential remains constant, suggests that the reducible species is monomeric. The upper concentration limit $([\mathrm{U}(\mathrm{VI})]=4 \mathrm{~m} M)$ was determined by solubility.

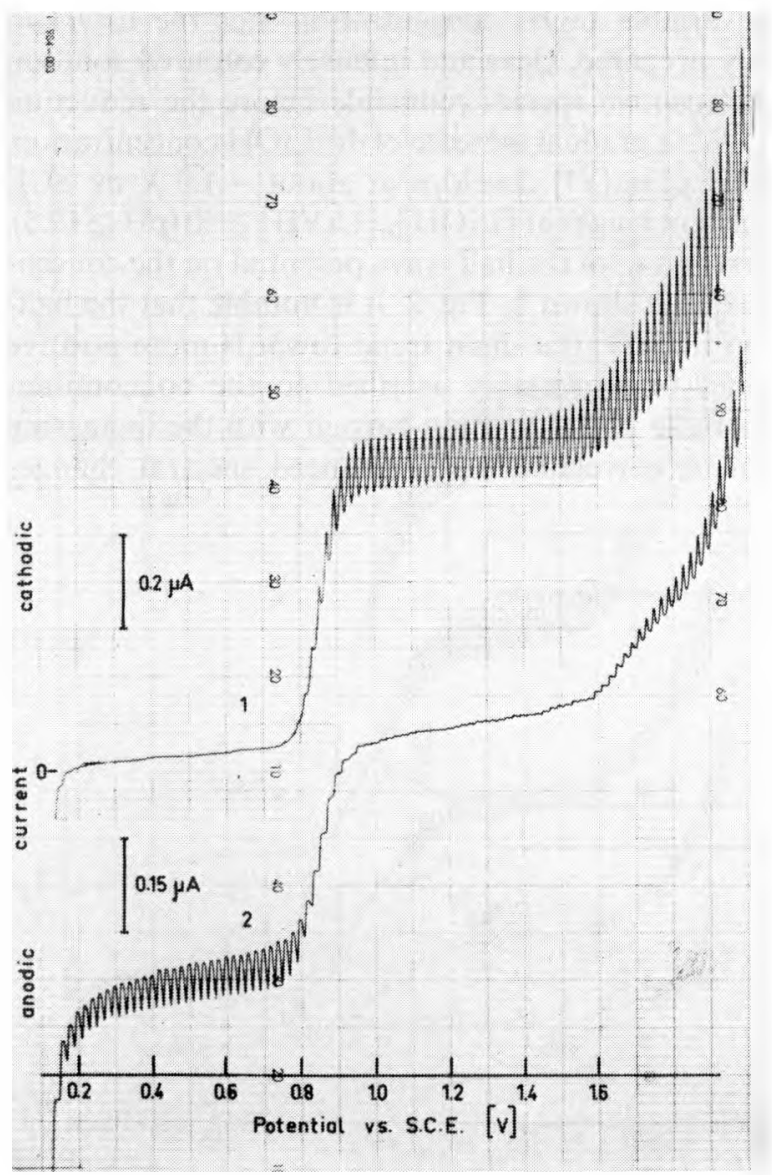

Fig. 3. Polarograms of soln. of $1 \mathrm{mM}$ uranium(VI) in $1 \mathrm{MLiOH}$ before (1), and after (2) potentiostatic reduction at $-1.1 \mathrm{~V} v$ s. SCE. 

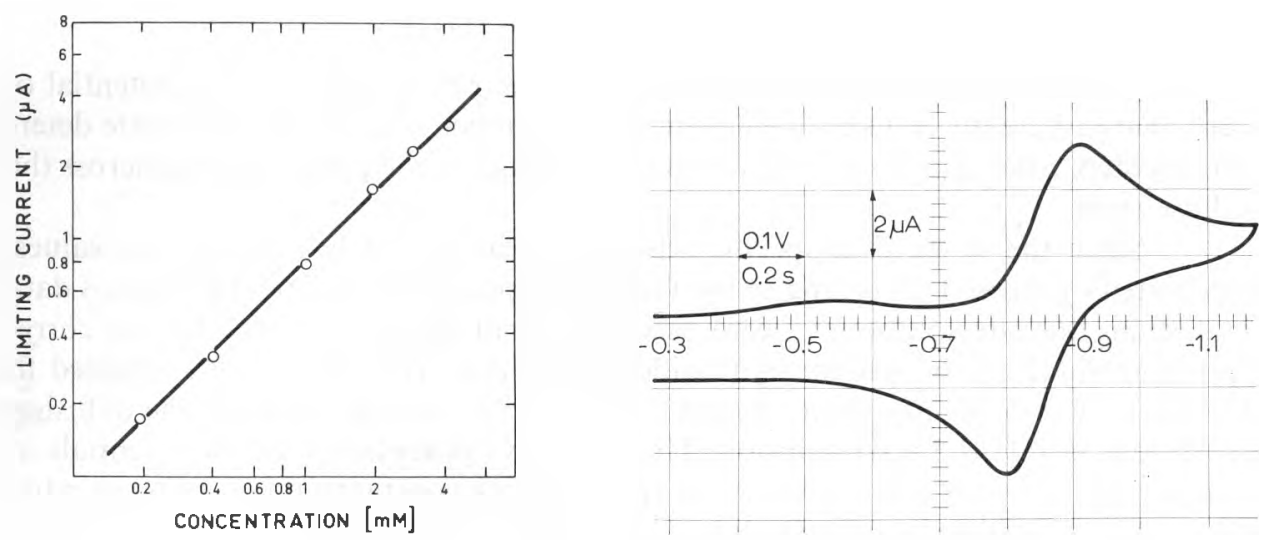

Fig. 4. Plot of limiting current $i s$. conen. of uranium(VI) in I $M$ LiOH solns.

Fig. 5. Cyclic voltammetric curve at the hanging mercury drop electrode in soln. of $1 \mathrm{mM}$ uranium(VI) in $2 \mathrm{M} \mathrm{LiOH}$. Sweep rate, $0.5 \mathrm{~V} \mathrm{~s}^{-1}$.

In order to identify the product of the electrode reaction, potentiostatic electrolysis at $-1.1 \mathrm{~V} v \mathrm{~s}$. SCE was performed on a large mercury pool electrode. The total quantity of electricity required $(n=0.98 \pm 0.05)$ closely corresponds to a oneelectron process. The resulting solution displays an anodic wave at $E_{1_{1}}=-0.88 \mathrm{~V} v \mathrm{v}$. SCE (Fig. 3, curve 2) corresponding to the oxidation of uranium(V) to uranium(VI). The amplitude of the anodic wave is, however, smaller than the initial one as a result of partial precipitation of uranium $(\mathrm{V})$ during the course of the experiment. Uranium(V) prepared by reduction of a $1 \mathrm{mM}$ solution of uranium(VI) in $\mathrm{LiOH}$ has a "half-life" of less than $10 \mathrm{~min}$. The precipitation is almost quantitative and, in the range of lithium concentrations studied $(0.1-2 M)$, no stable solution of uranium(V) could be detected polarographically. The black precipitate formed was separated and its $\mathrm{O} / \mathrm{U}$ ratio was found to be 2.5 , using the polarographic procedure devised by Sipos and Branica ${ }^{15}$. In contrast, the precipitation process is too slow to affect the anodic peak of uranium(V) displayed on fast sweep voltammetric curves (Fig. 5), in which peak separation corresponds to a quasi-reversible process. No disproportionation of uranium(V) could be detected in these experiments.

\section{Influence of the ionic strength}

With ionic strength decreasing below 1 , the wave of uranium(VI) maintains a quasi-reversible character, while below $0.2 \mathrm{M} \mathrm{LiOH}$ it becomes totally irreversible and appreciably shifted towards more negative potentials (this being in agreement with the results of Gierst and Lemaire ${ }^{4}$ ). The limiting current remains controlled by diffusion. The corresponding $\log \chi_{1}$ vs. potential plots constructed after WeberKoutecky ${ }^{16}$ are given in Fig. 6 . A rather short drop time $(1 \mathrm{~s})$ has been chosen to enhance the extent of irreversibility. The obvious retardation of the electrode process could be explained by the effect of the electrical double layer upon the kinetics of reduction of a negative particle ${ }^{17}$. Therefore the irreversible curves in Fig. 6 (curves for $0.2,0.1,0.075$ and $0.05 \mathrm{M} \mathrm{LiOH}$ ) were further analysed to evaluate their true kinetic parameters according to the Frumkin relation: 


$$
k_{\mathrm{a}}=k_{0} \exp \left(\alpha n_{x} F / R T\right)\left[-\left(E-E_{z}\right)-\left(z / \alpha n_{x}-1\right) \phi_{2}\right]
$$

where $k_{\mathrm{a}}$ is the apparent rate constant, $k_{0}$ the true rate constant at the potential of zero charge $E_{z}, \alpha$ the transfer coefficient, $n_{\alpha}$ the number of electrons in the rate determining step, $z$ the charge of the reaction particle and $\phi_{2}$ the potential drop across the diffuse layer.

Since the absence of specific adsorption can be safely assumed, $\phi_{2}$ values, calculated by Russell according to the Gouy-Chapman theory from Grahame's data in sodium fluoride solutions ${ }^{18}$ were used instead of the data lacking for the corresponding solutions of lithium hydroxide. The curves from Fig. 6 were adapted to the $\log k_{\mathrm{a}}-E$ coordinates using $D=8.4 \times 10^{-6} \mathrm{~cm}^{2} \mathrm{~s}^{-1}$ as the value for the diffusion coefficient in $0.1 \mathrm{M} \mathrm{LiOH}$ solution. The half-wave potentials (i.e. the potentials at comparable current), and the values of apparent rate constants at constant potential $\left(E=-1.1 \mathrm{~V} v\right.$ s. SCE) have been plotted against the corresponding $\phi_{2}$ values (Figs. 7 and 8). The slopes of the resulting straight lines, $\left(1-z / \alpha n_{x}\right)=3.2$ and $\left(z-\alpha n_{x}\right)=$ -1.52 , give $z=-1$ as value for the charge of the reacting particle, and $\alpha=0.49$ for the transfer coefficient (since $n_{x}=1$ ).
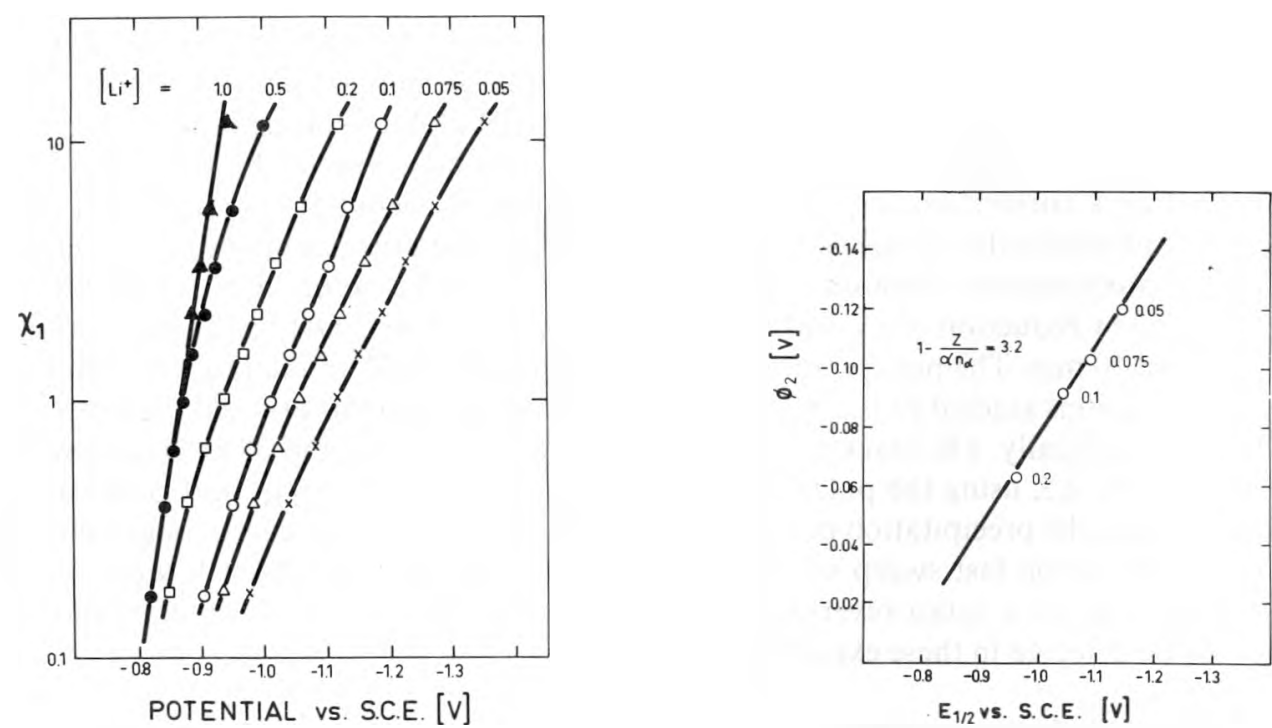

Fig. 6. Log $\chi_{1}$-potential curves for uranium(VI) reduction in $1,0.5,0.2,0.1,0.075$ and $0.05 \mathrm{MLiOH}$ supporting electrolyte (drop time $=1 \mathrm{~s}$ ).

Fig. 7. Plot of half-wave potentials of uranium(VI) wave vs. $\phi_{2}$ for different concns. of LiOH.

Figure 9 shows the effect of the potential upon the experimental $(0.1 \mathrm{M} \mathrm{LiOH}$ solution) and the true rate constant, calculated for $z=-1$ and $\alpha=0.49$. Since the electrode process under study is obviously a simple one, involving no change in the number of hydroxo ligands, the half-wave potential of the reversible wave, $E_{1}=$ $-0.88 \mathrm{~V} v \mathrm{~s}$. SCE, could be taken to represent the standard formal potential $E^{0}$ of the $\mathrm{U}(\mathrm{VI}) / \mathrm{U}(\mathrm{V})$ couple in alkaline solutions. The value of the true rate constant at this potential, $k=3.5 \times 10^{-2} \mathrm{~cm} \mathrm{~s}^{-1}$, represents the standard formal rate constant $k^{0}$. 

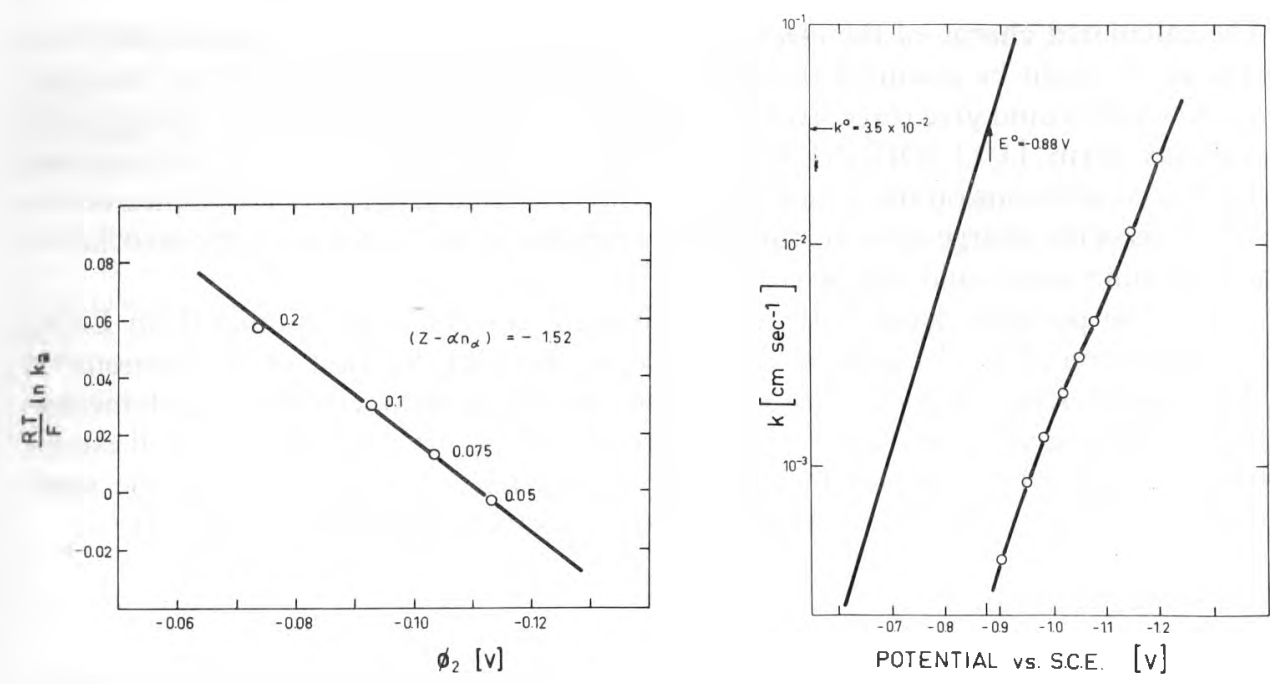

Fig. 8. Plot of apparent rate constants of uranium(VI) reduction at constant potential $(E=-1.1 \mathrm{~V} v$ s. SCE) $v s . \phi_{2}$ at different concns. of LiOH.

Fig. 9. Rate constant-potential dependence for reduction of uranium(VI): exptl. values in $0.1 \mathrm{MLiOH}$ supporting electrolyte $(\mathrm{O})$, and true value obtained after the Frumkin correction was made.

\section{DISCUSSION}

The results presented indicate conclusively that the electrochemical reduction of uranium(VI) to uranium(V) in lithium hydroxide solutions implies a simple electron transfer with $E^{0}=-0.88 \mathrm{~V} v$ s. SCE, $\alpha=0.49$ and $k^{0}=3.5 \times 10^{-2} \mathrm{~s}^{-1}$. These values are not significantly different from those proposed by Lemaire ${ }^{19}$ for the unstable species of uranium(VI) in sodium hydroxide solutions $\left(E^{0} \approx-0.8 \mathrm{~V} v \mathrm{~s}\right.$. SCE, $\left.k^{0}<10^{-2}\right)$. Furthermore, the values obtained are in line with the general trend of the electrochemical behaviour of the uranyl group in various complexing systems, which is characterized by the relatively fast electron transfer located on the uranyl group $\left(10^{-1.3} \geqq k^{0} \geqq 10^{-2.5}\right)$, but with pronounced shifts of the potential of the $\left(\mathrm{UO}_{2}^{2+}\right)$ $\left(\mathrm{UO}_{2}^{+}\right.$) couple, from -0.18 to $-0.9 \mathrm{~V} v$ s. SCE, reflecting the relative stabilities of the corresponding complex forms.

On the other hand the uranyl group represents an extremely stable structure which has been proved to exist in water solutions under all conditions studied so $\mathrm{far}^{20}$, even in the uranium(VI) triperoxo complex in $6 \mathrm{M} \mathrm{LiOH}$ solution ${ }^{21}$. Accordingly, it seems to us that there is no fact presently available to consider that it could be unstable or destroyed in alkaline solutions only.

In this direction, it seems fairly justified to represent the electroactive uranium(VI) as a six coordinated uranyl aquo hydroxo complex $\left[\mathrm{UO}_{2}(\mathrm{OH})_{6-n}\left(\mathrm{H}_{2} \mathrm{O}\right)_{n}\right]^{n-4}$ as proposed by Chernyaev ${ }^{5}$. The relatively high value of $k^{0}$ gives evidence that no strong uranium-oxygen bonds are broken during the electrode process, which consequently could be represented as:

$$
\left[\mathrm{UO}_{2}(\mathrm{OH})_{6-n}\left(\mathrm{H}_{2} \mathrm{O}\right)_{n}\right]^{n-4}+e \rightleftarrows\left[\mathrm{UO}_{2}(\mathrm{OH})_{6-n}\left(\mathrm{H}_{2} \mathrm{O}\right)_{n}\right]^{n-5}
$$


The calculated charge of the electroactive species, $z=-1$, corresponds to the bulk species. It might be assumed that this is equal to the ionic valence of the complex. $n-4$, which would give three hydroxo ligands coordinated to the uranyl group in the complex form $\left[\mathrm{UO}_{2}(\mathrm{OH})_{3}\left(\mathrm{H}_{2} \mathrm{O}\right)_{3}\right]^{-}$, already proposed ${ }^{5}$. However, for making definite conclusions on the structure of the electroactive uranium(VI) complex on the sole basis of the charge $z$, the possibility of a net charge decrease due to the association with lithium ions could not be ruled out ${ }^{22}$.

The peculiar dependence of the limiting current of uranium(VI) on $\mathrm{LiOH}$ concentration (Fig. 2) could be correlated to the bulk fraction of the monomeric electroactive form. This conclusion is substantiated by the facts that $(a)$ polymerisation of the uranyl ion with increasing hydrolysis in the $\mathrm{pH}$ region 4-10 is well established ${ }^{1,2}$, and $(b)$ the polymeric complex $\mathrm{U}_{3} \mathrm{O}_{8}(\mathrm{OH})_{m}^{2-m}$ responsible for the spectrum $^{2,6,11}$ at $\mathrm{pH}=10.2$ has been proved to be electroinactive (Fig. 1, curve 1).

\section{ACKNOWLEDGEMENT}

The authors wish to express their appreciation to Prof. L. Gierst for helpful discussions.

SUMMARY

A study of the U(VI)/U(V) couple in lithium hydroxide solutions has been carried out by polarography, at concentrations of uranium(VI) and lithium hydroxide at which the former is soluble and stable.

Electrochemical reduction of uranium(VI) was found to be $\mathrm{pH}$ independent and the limiting current diffusion controlled; uranium(V), identified as the product, precipitates, but does not undergo disproportionation. The electrode process is reversible at $\mathrm{LiOH} \geqq 1 M$, while at $\mathrm{LiOH} \leqq 0.2 M$ it is totally irreversible. The standard potential of the $U(V I) / U(V)$ couple has been evaluated from the reversible behaviour. The charge of the electroactive species $(z=-1)$, the transfer coefficient $(x=0.49)$ and the standard formal rate constant $\left(k^{0}=3.5 \times 10^{-2} \mathrm{~s}^{-1}\right)$ were evaluated from the irreversible waves applying the Frumkin correction for the double layer. The nature of the hydrolysed species of uranium(VI) and uranium(V) in highly alkaline solutions is discussed and a kinetic scheme is proposed for the electrode process.

\section{REFERENCES}

1 L. G. Sillên And A. E. Martell, Stability Constants of Metal-Ion Complexes, Chemical Society, London, 1964, p. 50.

2 I. J. Sutton, J. Chem. Soc., (1949) 275.

3 A. M. Gurevich and L. D. Preobrazhenskaya, Zh. Neorgan. Khim., 3 (1958) 2517.

4 L. Gierst and J. Lemaire, EURAEC-876, Quart. Rpt. No 12, July I-September 30, 1963.

5 I. I. Chernyaev, Kompleksny'e soedineniya urana, Nauka, Moskva, 1964, pp. 55-65.

6 B. Tomažıč, V. Žutić and M. Branica, Inorg. Nucl. Chem. Letters, 5 (1969) 271.

7 B. Tomažıč, M. Branica And B. Težak, Croat. Chem. Acta, 34 (1962) 41.

8 H. Fû́redi And B. TeŽAK, Croat. Chem. Acta, 36 (1964) 119.

9 H. Füredi, Croat. Chem. Acta, 36 (1964) 195.

10 B. Tomažıč and M. Branica, Croat. Chem. Acta, 38 (1966) 249. 
11 B. Tomažıčc, M. Samardžija and M. Branica, J. Inorg. Nucl. Chem., 31 (1969) 1771.

12 V. ŽUTIĆ AND M. Branica, to be published.

13 V. Žutić and M. Branica, J. Polarog. Soc., 13 (1967) 9.

14 Gmelins Handbuch der Anorganischen Chemie, 8. Auflage, No. 55, p. 136.

15 L. Sipos and M. Branica, J. Polarog. Soc., 14 (1968) 3.

16 J. Weber and J. KouteckÝ, Collection Czech. Chem. Commun., 20 (1955) 980.

17 P. Delahay, Double Layer and Electrode Kinetics, Interscience, New York, 1965, chap. 9.

18 C. D. Russell, J. Electroanal. Chem., 6 (1963) 486.

19 J. LemalRe, Thèse de doctorat, Universite Libre de Bruxelles, 1965.

20 F. A. Cotton and G. Wilkinson, Advanced Inorganic Chemistry, Interscience, New ·York, 1966.

21 N. W. Alcock, J. Chem. Soc., (A) (1968) 1588.

22 L. Gierst, L. Vanderberghen, E. Nicolas and A. Fraboni, J. Electrochem. Soc., 113 (1966) 1025.

J. Electroanal. Chem., 28 (1970) 187-195 